\title{
Exploration and Practice of Ideological and Political Work in Party Construction to Improve Quality and Efficiency of Scientific Research Work in Universities
}

\author{
Dong Shengrong ${ }^{1}$, Liu Zhu ${ }^{1}$ \\ 1. Qingdao Ocean Shipping Mariners College, China 266071 \\ E-mail:dongshr@coscoqmc.com.cn
}

Key words: Ideological and Political Work in Party Construction; Scientific Research of University; Improve Quality and Efficiency; Exploration and Practice

\begin{abstract}
The study of Ideological and political work in Party construction promotes the quality and efficiency of scientific research work in universities. It not only has a solid academic foundation, but also has an important practical value. By improving the scientific management mode, reform the management system of scientific research and stable management team, From the perspective of strengthening system, lowering cost, and promoting efficiency, the multi-views prove the protection and promotion of ideological and political work in Party construction in the quality and efficiency of scientific research work of colleges and universities. The quality and efficiency of scientific research work in universities can not be separated from the ideological and political work of Party Construction, which is determined by the fundamental nature of our universities.
\end{abstract}

\section{Introduction}

It is viewed in $18^{\text {th }}$ National Congress of Communist Party of China, adhering to the principle of giving priority to the development of education, carrying out the party's educational policy in an all-round way, and adhering to the fundamental task of serving the socialist modernization, bringing up all round development of morality, intelligence, physics and arts.

General secretary Xi Jinping pointed out at the twenty-third national college party construction conference that the fundamental goal of the construction of colleges and universities is to run good Chinese socialist university. The major task of colleges and universities is to study and disseminate Marxist ideas, cultivate the qualified constructors and successors for the socialist undertaking with Chinese characteristic. The fundamental guarantee of running a socialist university with Chinese characteristics is to reinforce the construction of the Chinese communist Party and its leadership over the institutions.

Our colleges and universities are not only the socialist nature of the university, but also are Chinese characteristics, they raises the great task of "study and disseminate Marxist ideas, cultivate the qualified constructors and successors for the socialist undertaking with Chinese characteristic, take high moral values establishment and people cultivation, bring the socialist core values into the whole process of teaching and educating people. strengthen the ideological guidance, firmly grasp the leadership of college ideological leadership; Stick to and improve the principal accountability under the leadership of the party committee, continue to reform and improve the system mechanism; promote the work of Party construction comprehensively, strengthening the construction of grass-roots Party organizations and role models effectively.

Earnestly study and implement the general secretary Xi Jinping important speech about the ideological and political party construction work in universities in the party spirit, is the central premise of school governance remain highly consistent, is an important way to improve the party committees at all levels of work ability and leadership skills under the new situation. The scientific research is one of the four main functions of colleges, not only bear the responsibility of the proposed guidance on university scientific research direction and task, but also has direct effect on the development of college leadership on research planning, project reporting, scientific research, scientific research evaluation etc. The quality of scientific research in universities will directly 
affect the improvement of scientific research level, the cultivation of qualified personnel with high quality and the sustainable development of universities.

Therefore, to study and explore the ideological and political work of Party construction and to promote the quality and efficiency of scientific research in universities, not only has a solid academic foundation, but also has important practical application value.

\section{Ideological and political Party construction is the enter point of scientific research work in universities.}

It is pointed out in the third Plenary Session of the 18th CPC Central Committee, "innovate grassroots party construction work, improve the construction of primary Party organization, play the role of fighting bastion and the core of leadership of the Party branch, guide the majority of Party members to join the reform actively, carry forward the 'nail' spirit, step stone to stay marks, grip iron to stay trace, make a positive contribution to the comprehensive deepening reform."

Compared with the teaching management in universities, scientific research management lack of fixed mode, it is a multitude of things, and more difficult to manage. It has not reached the desired level in education and management system. Colleges and universities have met the bottleneck in making full use of the advantages of talents and improving the level and level of scientific research. There are many problems need to be improved, it's urgent to improve quality and efficiency.

According to the investigation, there are three main problems in scientific research work in universities. First of all, the management model of passive service needs to be improved. Most of the scientific research management departments are still located in the administrative departments, there are different degrees of emphasing on scientific research instead of management, the constraint instead of excitation, the result instead of process, the development instead of conversion thinking, lack of professional research management staff. The management of scientific research personnel only plays an essential role for the clerk, issues notice and form, submits report, sends the file, they are unable to gives full play to their initiative, always in a completely passive state of service, to a great extent, the management of scientific research is restricted.

Secondly, the scientific research management system that guides dislocation needs to be reformed. The scientific research management system of many domestic colleges and universities often ignore the correct guidance of teachers' scientific research value, only by obtaining the number of research projects, the project level and funding, the number of SCI papers and levels etc., a series of quantitative indicators to measure the scientific research work, this quantitative assessments are closely related to the researcher's job classification, promotion, tutor selection, projection reporting and other vital interests. As a result, college teachers engaged in scientific research, and the research situation for them was endless. This management system lead to serious dislocation of teachers' scientific research values, facing fierce competition situation, a number of researchers has lost their academic fame, giving up adhering to the moral line, there has been a lot of academic misconduct, such as plagiarism, plagiarism, fabrication and tampering, Seriously deviated from the soul of seeking scientific truth and innovation research.

Thirdly, the weak scientific research management team needs to be stabilized. Scientific research management has dual functions of both academic management and administrative management, not only undertake the dissemination of scientific thought, carry out many task of project management, financial management, product management, but also provide hardware and software policy support for research team, scientific research institutions and innovative energy for the construction of the scientific and technological innovation. This requires management of scientific research workers must have good comprehensive management capabilities, Moreover, the administrative color of scientific research management in many colleges and universities is still relatively strong, The existence of the duty boundary is not clear, the policy orientation is not effective, inefficient allocation of resources and so on, Moreover, most of them tend to have bad tendencies, such as emphasizing use and ignoring training bad tendencies, lack of the necessary reward constraint, performance appraisal, supervision, inspection and other personnel comprehensive evaluation mechanism lead to low enthusiasm and mobility of managers. 
Through the above investigation and analysis, the most important problems in scientific research work in universities are "human" problems, and it is an important way to promote the quality and efficiency of scientific research work in universities. And this precisely finds entry point for Party ideological and political construction work to promote scientific research work quality and efficiency.

\section{Multi-perspectives prove ideological and political Party construction work guarantees and promotes the quality and efficiency of scientific research work in universities.}

General secretary Xi Jinping said in the 100th Western Returned Scholars Association (WRSA) anniversary that "innovation is the soul of a nation's progress, is an inexhaustible driving force national prosperity, it is also the most miraculous national gift of the Chinese nation. In the fierce international competition, only reform can progress, only innovation can be powerful, and only reform and innovation can win.

Through in-depth study and implement of the general secretary Xi Jinping governing the new concept of new ideas and new strategy, In particular, we should deeply grasp the important instructions of general secretary Xi Jinping on Party building and scientific and technological innovation work in colleges and universities. It has important and far-reaching guiding significance for innovating the ideological and political work of the party construction at the grass-roots level of universities and promoting the quality and efficiency of scientific research work in universities.

\subsection{From the point of view of "strength management", it has great room to improve the scientific research work in universities.}

From the investigation and analysis above, there are three scientific research work need to be strengthened in universities. First is to improve the management mode of scientific research in universities. Second is to reform the management system of scientific research in universities, and third is to build a high-quality and stable contingent of scientific research management in universities. These three aspects need to be coordinated. With the reform of management system in Universities, deepen the scientific research management construction of system and mechanism in universities, mobilize involvement and motivation of people are as strong as possible. Further stimulate technological innovation and vitality, firmly leading university science and technology innovation direction, abandon a variety of academic misconduct, create healthy academic atmosphere, gradually establish the unity of right and duty, incentive and restraint, both the protection and regulation of peers, stability and innovation of both scientific research and innovation evaluation mechanism and management platform, inject tonic to promote the quality and efficiency of scientific research work in universities.

This not only puts forward high requirements for the professional quality of scientific research, technical personnel and administrators in universities, but also puts forward new requirements for their ideological and political quality. First, requirements of scientific and technical personnel and management personnel in universities must have unknown to the public, work hard, service for teachers and people wholeheartedly, a correct view of individual and school, dedication and fame, and always adhere to the people-oriented attitude.

Secondly, requirements of scientific and technical personnel and management personnel in universities must establish a firm belief in socialism, uphold leadership of the party, keep to the socialist road, insisted to the principle which cadre must have both ability and integrity, hold to the correct political direction, which is not for the complicated social factors, timely problems in the industry initiative, always keep correspondence with the Party Central committee, so that scientific research can truly contribute to the realization of the Chinese dream。

Thirdly, Requirements of technicians and administrators in universities must have a high degree of integrity and noble professional ethics. The scientific research technology inevitably involves the patent and the and intellectual property rights. The achievements of researchers in the course of research are patent, we must pay attention to confidentiality of research data. At the same time, on the use and management of scientific research funds, we should cultivate consciously a diligent and 
honest work style, eliminate and resist the influence of some negative factors, ensure the research funds are earmarked and the projects are completed smoothly.

\subsection{From the point of view of "lowering cost", reduce the cost of scientific research in universities has a very broad operating space.}

From the previous investigation and analysis, we found that reducing the cost of scientific research work in universities can focus on the following two aspects. On the one hand, the reform of the scientific research management system can realize effective docking of scientific research resources, lower the cost of university scientific research system; on the other hand, take the initiative to lead the direction of scientific research, improve the accuracy of scientific research greatly and reduce the development of science and technology investment effectively.

It also puts forward new heights and requirements for the professional and ideological quality of technicians and administrators in universities. From one thing, requirements of technicians and administrators in universities must treasure every cent, always establish the thought of hard work, correctly handle the relationship between development and outsourcing, always stick to working attitude of strict economy.

For another, requirements of technicians and administrators in universities must seriously conduct market research, always establish application innovation ideas, close to the market demand to carry out scientific research, reduce the initial investment of scientific and technological development, pay attention to saving in the process of development expenditure, to achieve maximum benefits with the minimum investment.

\subsection{From the perspective of "promoting efficiency", it is of great market prospect to improve the efficiency of scientific research work in universities.}

From the previous investigation and analysis, it is not difficult to find that promoting the efficiency of scientific research work in universities should be carried out in the following two aspects. On the one hand, try hard to realize the overall budget management method of scientific research and scientific innovation factor in Universities, reduce the risk of university scientific research management; on the other hand, grasp the pulse of the market demand of science and technology initially, shorten the scientific research development cycle as much as possible, improve the conversion efficiency of university scientific research.

This once again puts higher forward requirements for the professional and ideological quality of technicians and administrators in universities. On the one hand, requirements of technicians and administrators in universities must tighten the "benefit" of the string, always set the priority of benefits, pay attention to the effective allocation of human, financial and material resources, and rational restructuring, eliminate the mutual differences of resources system and target management, correctly handle the relationship of input and output, stick to create the benefits of working attitude. On the other hand, requirements of scientific and technical personnel and management personnel in universities must focus on market demand, always establish the efficiency of the thought, and constantly improve the risk investment and cross financing system, promote the development and utilization of scientific achievements, improve the technology market system, accelerate the combination of research and production, promote the commercialization of the scientific and technological achievements, promote science and technology into productive forces effectively.

\section{Conclusion}

The development of universities can not be separated from the continuous improvement of teaching quality and the promotion of scientific research ability. As the source of promoting the continuous development of universities, both are the major task of the work of universities. To further strengthen the connection between ideological and political work in Party construction and scientific research work in universities, It benefits for guarantee and promotion function of ideological and political party construction work.

We should not only form university research service on the ideological and political work from the consciousness, but also perfect the guarantee mechanism to promote the development of 
scientific research in universities according to system, more efforts should be made to explore the effective way for ideological and political work in the party construction to serve the scientific research work in universities, explore new ideas and new methods of ideological and political work in Party construction constantly.

By looking at a problem in as many ways as possible, it is no doubt that ideological and political Party construction work on the quality and efficiency of scientific research work in universities advance in promoting. based on people-oriented, give full play to the party organizations fighting force, make full use of the leading effect of the Party, focusing on methods and approaches of improving quality and efficiency in scientific research work, It is entirely possible to promote the scientific research work in universities as an important indicator of ideological 1 work in the party. The quality and efficiency of scientific research work in universities cannot be separated from the ideological and political work of Party construction. It is determined by the fundamental nature of the institutions of universities in china.

\section{Acknowledgements}

This work was financially supported by the Class A Project of Shandong Province Higher Educational Science and Technology Program (J17RA228) and the Research Project of Qingdao Ocean Shipping Mariners College (2017010).

\section{References}

[1] Huang Jiali. Research on Business Process Reengineering of Scientific Research Project Management in Universities [J]. Management Observer, 2016, (31) (in Chinese)

[2] Cheng Juanjuan. Strategy Research on Improving the Efficiency of Scientific Research Management in Institutions of Higher Learning [J]. Educational Review, 2016, (8) (in Chinese)

[3] Wang Wei. Significance, Orientation and Promotion Strategy of Scientific Research Work in Higher Vocational Colleges [J]. Journal of Liaoning Higher Vocational, 2016, (9) (in Chinese)

[4] Zeng Ling. Innovative Thinking of Ideological and Political Work of Party Construction at Basic Level Enterprises [J]. Inheritance \& Innovtion, 2015, (9) (in Chinese)

[5] Li Fensheng, Mei Dahai. A Research on Government Behavior Optimization of Enterprise Technological Learning [J]. Science Research Management, 2015, (1) (in Chinese)

[6] Yang Deshan. Some thoughts on scientific research management in innovative Colleges [J]. Technology Outlook, 2015, (1) (in Chinese)

[7] Zhang Lijun. Analysis of the Integration of Ideological and Political Work and Production Management in Grass Roots Party Construction [J]. China Management Informationization, 2014, (1) (in Chinese)

[8] Shi Hongjia. Promoting Party and Ideological Construction at University with Spirit of Reforming and Innovation [J]. Journal of Qujing Normal Universoty, 2014, (1) (in Chinese)

[9] Li Ping. The Importance and Development of Ideological and Political Work in Grass Roots Party Construction [J].Reform \& Openning, 2013, (1) (in Chinese)

[10] Wei Jinggang, Shi Junxiang. Reflections on Party Construction at the grass-roots level in Colleges and universities in the new era $[\mathrm{J}]$. Journal of the Party School for the Departments Directly under Shanxi Provincial Committee of the CPC, 2016, (4) (in Chinese)

[11] Zhang Tieshan. Research on the boosting mechanism of scientific and technological innovation and entrepreneurial achievements transformation in Henan Universities [J]. Journal of Luohe Vocational Technology College, 2011, (6) (in Chinese) 